\title{
Application of the biopreparation 'Orgamika F' against fusarium disease of cabbage and other cole vegetables
}

\author{
Abdurakhman Allayarov ${ }^{1 *}$, Mirakbar Zuparov ${ }^{1}$, Albert Khakimov ${ }^{1}$, and Alisher \\ Omonlikov ${ }^{1}$ \\ ${ }^{1}$ Tashkent State Agrarian University, 100140, Tashkent province, Uzbekistan
}

\begin{abstract}
This article provides information on the spread, development and damage of fusarium disease, which occurs in cabbage vegetable crops (white cabbage, cauliflower, broccoli, red cabbage, savoy cabbage, Chinese cabbage) and the use of biological preparations against this disease. Healthy and vigorous seedlings were obtained when fusarium disease was treated with a titrated suspension Orgamica $\mathrm{F}$ of $1 \cdot 10^{8} \mathrm{CFU}$ (colony forming unit) $/ \mathrm{ml}$, and the number of diseased seedlings was $0.6-$ $1.0 \%$. It was noted that $0.9-1.3 \%$ of seedlings from seeds treated with a titrated suspension of the preparation $1 \cdot 10^{4} \mathrm{CFU} / \mathrm{ml}$ were infected with fusarium disease. Also, in the experiment, a option that showed high biological efficacy against white fusarium disease: Orgamika $\mathrm{F}$ biopreparation 3 times, ie with a suspension of $1 \cdot 10^{8} \mathrm{CFU} / \mathrm{ml}$ titer per seed before sowing, $2 \%$ suspension of the biopreparation $\left(2 \cdot 10^{6} \mathrm{CFU} / \mathrm{ml}\right.$ titration suspension). It is recommended to apply the biopreparation to the seedling root before planting and 15 days after planting in the field with a suspension of $0.25 \%$ concentration $(2.5 \cdot 104 \mathrm{CFU} / \mathrm{ml}$ titration) under production conditions.
\end{abstract}

\section{Introduction}

Among vegetables, cole vegetables (white cabbage, cauliflower, broccoli, Chinese cabbage, Beijing cabbage, and savoy cabbage) have a special place. In 2017, the total area planted cabbage in the world was about 2.5 million hectares, and cabbage and cabbage vegetables were grown 71.45 million tons [1, 2]. In 2017, Uzbekistan produced 23 million tons of fruits and vegetables. At present, cabbage is the third largest vegetable crop in the country after tomatoes and onions [3, 4], of which in 2017 the production of cabbage reached 904,000 tons $[1,2]$.

The homeland of cabbage is the Mediterranean coast, which belongs to the category of very ancient crops [5]. Although the composition of cabbage is not rich in nutrients, it is a source of minerals, vitamins and especially vitamin $\mathrm{C}[6]$.

Cabbage vegetable crops are affected by a number of viral (Cauliflower mosaic virus, Turnip mosaic virus), bacterial (Pseudomonas syringae. pv. maculicola, Erwinia spp,

* Corresponding author: agrobiotechinfo@,yandex.ru 
Xanthomonas campestris pv. campestris) and fungal (Alternaria brassicae, Phoma lingam, Fusarium oxysporum $f$. sp. conglutinans, Verticillium dahliae, Sclerotinia sclerotiorum, Mycosphaerella brassicicola, Peronospora parasitica, Plasmodiophora brassicae, Pythium spp., Fusarium spp., Rhizoctonia solani) diseases during growth, development and storage $[7,8]$. Among these diseases, fusarium disease is one of the most dangerous diseases, which reduces not only the yield but also the quality of cabbage vegetable crops. Therefore, the study of this disease and the development of measures to combat it is one of the most pressing issues [9].

The uncontrolled and careless use of synthetic pesticides can lead to soil contamination with pesticides, the emergence of extremely high resistance to pests, a sharp increase in the amount of pesticide residues in consumer products, the destruction of beneficial organisms and, most importantly, human health $[10,11]$. In order to prevent such cases, it is necessary to use synthetic pesticides only when the pest exceeds the economic threshold, or to replace synthetic pesticides with biologically based substances, microbial producers and biopreparations based on colony forming units (CFU) $[12,13]$.

A number of scientists have reported data on the emergence of pathogen resistance to synthetic fungicides, which in turn leads to the use of biofungicides against pathogenic fungi [14-16].

In recent years, much attention has been paid to environmentally friendly biological control measures as an alternative to traditional chemical fungicides against plant diseases [1]. Today, more than 40 biopreparations are produced in the world [17]. One of the most promising new directions in the protection of agricultural crops from phytopathogens is to increase the induction of plant resistance to pathogens and adverse environmental factors using these biopreparations [18].

Although phytopathological and mycological research has been conducted in the Republic of Uzbekistan for many years [19], almost no research has been conducted on the implementation of biological control measures against fusarium disease of cabbage and cole vegetable crops. Thus, this research paper is devoted to determining the effectiveness of biological preparations against fusarium disease in cabbage and cole vegetable crops.

\section{Materials and methods}

Prior to sowing the seeds of vegetable crops against fusarium disease, laboratory experiments were carried out in pots to study the effectiveness of treatment with Orgamika F biopreparation of the Russian company 'Bionovatic', based on the fungus Trichoderma asperellum, which is an antagonist of pathogenic fungi. Organic F biopreparation contains a strain of Trichoderma asperellum (VKPM/F-1323) with a titer of $1 \cdot 10^{8} \mathrm{CFU} / \mathrm{ml}$ and is produced in liquid form. To create an infectious background, culture fluids of phytopathogenic fungus $F$ oxysporum $f$ conglutinans grown in beer wort under laboratory conditions and with a titer of $1 \cdot 10^{6} \mathrm{CFU} / \mathrm{ml}$ were used. The cultured liquids of the phytopathogenic fungus were placed in pots mixed with $0.5 \mathrm{ml} / \mathrm{kg}$ each and kept in these pots at a temperature of 22-24 for 7 days, and the seeds of related vegetable crops were sown in 20 pots in each pot.

The experiments were performed in two different options, i.e., the seeds were soaked for 24 hours in titrated suspensions of Orgamika F biopreparation in a 2:1 ratio, 1.10 $\mathrm{CFU} / \mathrm{ml}$ and $1 \cdot 10^{8} \mathrm{CFU} / \mathrm{ml}$, and then sown. Each option was iterated four times.

The experiments in the next direction were carried out according to the following scheme. That is, Option 1: control - with water to the seed; Option 2: with Orgamika F to seed only; Option 3: with a 2\% fluid culture of Orgamika F to the seed and to the seedling root before planting; and, Option 4: Orgamika F was applied to the seed and root of the seedling before sowing with a $2 \%$ fluid culture (with a titration suspension of $2 \cdot 10^{6}$ 
$\mathrm{CFU} / \mathrm{ml})$ and with a $0.25 \%$ fluid culture $\left(2.5 \cdot 10^{4} \mathrm{CFU} / \mathrm{ml} 15\right.$ days after planting) was treated at the rate of $50 \mathrm{ml}$ of fluid culture under each seedling.

\section{Results and discussion}

Fusarium disease of cabbage vegetable crops is one of the most common and highly harmful diseases. One of the most effective methods of treatment against this disease is the treatment of seeds and seedlings with biopreparations before sowing [20].

Noting that, the list of pesticides and agrochemicals allowed in Uzbekistan [21] does not include insecticides or fungicides used during the growing season against fusarium disease caused by soil phytopathogen of cabbage vegetable crops.

Among the soil micromycetes, representatives of the Trichoderma family exhibit strong antagonistic properties, and biopreparations based on them are now being prepared in many countries around the world. When active strains of fungi belonging to this family are planted in the soil, mycelium develops from their spores, releasing about 9 antibiotics such as glycocin, viridine, alalitsin, and has a devastating effect on about 40 pathogens, including fusarium disease. This micromycet saprophyte is a soil sanitizer that does not develop in living cells and has a stimulating effect on plant development [22].

A biofungicide prepared on the basis of the antagonist fungus Trichoderma viride by Several researchers [23] has been shown to have positive results in the cultivation of tomatoes on artificial substrates against verticellosis. At the same time, when the artificial background of the disease was formed and the biofungicide was applied, the efficiency was $67 \%$, and the yield compared to the control was $2.6 \mathrm{~kg} / \mathrm{m}^{2}$.

As shown in Table 1, Seedling damage in the control was $36.3 \%$, followed by, $11.2 \%$ and $10.0 \%$ in cauliflower, $40.0 \%$ in control, $8.8 \%$ and $7.5 \%$ in Chinese cabbage, $32.5 \%$ in control, $12.5 \%$ and $10.0 \%$ in red cabbage. $\%, 41.3 \%$ in control, $8.8 \%$ and $7.5 \%$ in savoy cabbage, $31.3 \%$ in control, $6.3 \%$ and $5.0 \%$ in broccoli, $21.2 \%$ in control, and in kohlrabi $5.0 \%$, and $3.8 \%$, and in control $18.8 \%$.

Orgamika F biopreparation not only reduced the damage of cabbage vegetable crops by fusarium disease, but also affected the improvement of seedling quality indicators. From the experimental options, the best performance was shown by soaking the seed in a $1 \cdot 10^{8}$ $\mathrm{CFU} / \mathrm{ml}$ suspension of the biopreparation.

At the same time, the biological efficiency of Orgamika $\mathrm{F}$ biopreparation in white cabbage was $69.9 \%$ in the option fermented in a titrated suspension of $1 \cdot 10^{4} \mathrm{CFU} / \mathrm{ml}$, and $74.7 \%$ in the option fermented in a titrated suspension of $1 \cdot 10^{8} \mathrm{CFU} / \mathrm{ml}$. This figure is $72.2 \%$ and $75.1 \%$ in cauliflower, $72.5 \%$ and $76.2 \%$ in Chinese cabbage, $70.4 \%$ and $76.8 \%$ in red cabbage and $72.4 \%$ and $77.8 \%$ in savoy cabbage, $71.4 \%$ and $78.9 \%$ in broccoli, and $75.0 \%$ and $79.0 \%$ in kohlrabi, respectively (Table 2 ).

Before sowing the seeds of cabbage vegetable crops against fusarium disease, sowing them in a titrated suspension of Organic $\mathrm{F}$ biopreparation $1 \cdot 10^{8} \mathrm{CFU} / \mathrm{ml}$ not only reduces the disease, but also increases the germination of seeds. Therefore, before sowing the seeds, it is recommended to sow the seeds in a titrated suspension of Orgamika F biopreparation $1 \cdot 10^{8} \mathrm{CFU} / \mathrm{ml}$.

The conditions for the production of Orgamika $\mathrm{F}$ biopreparation based on the fungus Trichoderma asperellum antagonist against fusarium disease of white cabbage were tested in field experiments.

Production experiments were conducted in 2017 and 2018 on the farm "Fresh Rose" LLC in Ortachirchik administrative district of Tashkent province, Uzbekistan. The main reason for conducting the experiment on this farm is that white cabbage with fusarium disease is more affected here than other farms in the study, ie there is a natural infectious background of the pathogen Fusarium oxysporum f conglutinans. 
Table 1. Effect of treatment of seeds of cabbage vegetable crops with Orgamika F biopreparation on fusarium disease (laboratory experiments).

\begin{tabular}{|c|c|c|c|c|c|}
\hline \multirow[t]{2}{*}{$\#$} & \multirow[t]{2}{*}{ Experiment options } & \multirow{2}{*}{$\begin{array}{l}\text { Titer of preparation for } \\
\text { seed treatment (CFU/ml) } \\
\text { or discharge norms }\end{array}$} & \multirow{2}{*}{$\begin{array}{c}\text { Number of } \\
\text { seeds }\end{array}$} & \multicolumn{2}{|c|}{$\begin{array}{c}\text { Infection with fusarium } \\
\text { disease }\end{array}$} \\
\hline & & & & pes & $\%$ \\
\hline 1 & 2 & 3 & 4 & 5 & 6 \\
\hline \multicolumn{6}{|c|}{ White cabbage } \\
\hline 1 & Control & - & 80 & 29 & 36.3 \\
\hline 2 & \multirow{2}{*}{ Orgamika F } & $1 \cdot 10^{4}$ & 80 & 8 & 10.0 \\
\hline 3 & & $1 \cdot 10^{8}$ & 80 & 7 & 8.8 \\
\hline 4 & $\begin{array}{l}\text { Vitavax 200, 75\% } \\
\text { (standard) }\end{array}$ & $10 \mathrm{~g} / \mathrm{kg}$ & 80 & 9 & 11.2 \\
\hline \multicolumn{6}{|c|}{ Cauliflower } \\
\hline 1 & Control & - & 80 & 32 & 40.0 \\
\hline 2 & \multirow{2}{*}{ Orgamika F } & $1 \cdot 10^{4}$ & 80 & 9 & 11.2 \\
\hline 3 & & $1 \cdot 10^{8}$ & 80 & 8 & 10.0 \\
\hline 4 & $\begin{array}{l}\text { Vitavax 200, 75\% } \\
\text { (standard) }\end{array}$ & $10 \mathrm{~g} / \mathrm{kg}$ & 80 & 10 & 12.5 \\
\hline \multicolumn{6}{|c|}{ Chinese cabbage } \\
\hline 1 & Control & - & 80 & 26 & 32.5 \\
\hline 2 & \multirow{2}{*}{ Orgamika F } & $1 \cdot 10^{4}$ & 80 & 7 & 8.8 \\
\hline 3 & & $1 \cdot 10^{8}$ & 80 & 6 & 7.5 \\
\hline 4 & $\begin{array}{l}\text { Vitavax 200, 75\% } \\
\text { (standard) }\end{array}$ & $10 \mathrm{~g} / \mathrm{kg}$ & 80 & 8 & 10.5 \\
\hline \multicolumn{6}{|c|}{ Red cabbage } \\
\hline 1 & Control & - & 80 & 33 & 41.3 \\
\hline 2 & \multirow{2}{*}{ Orgamika F } & $1 \cdot 10^{4}$ & 80 & 10 & 12.5 \\
\hline 3 & & $1 \cdot 10^{8}$ & 80 & 8 & 10.0 \\
\hline 4 & $\begin{array}{l}\text { Vitavax 200, 75\% } \\
\text { (standard) }\end{array}$ & $10 \mathrm{~g} / \mathrm{kg}$ & 80 & 11 & 13.8 \\
\hline \multicolumn{6}{|c|}{ Savoy cabbage } \\
\hline 1 & Control & - & 80 & 17 & 21.2 \\
\hline 2 & \multirow{2}{*}{ Orgamika F } & $1 \cdot 10^{4}$ & 80 & 5 & 6.3 \\
\hline 3 & & $1 \cdot 10^{8}$ & 80 & 4 & 5.0 \\
\hline 4 & $\begin{array}{l}\text { Vitavax 200,75\% } \\
\text { (standard) }\end{array}$ & $10 \mathrm{~g} / \mathrm{kg}$ & 80 & 6 & 7.5 \\
\hline \multicolumn{6}{|c|}{ Brocolli } \\
\hline 1 & Control & - & 80 & 17 & 21.2 \\
\hline 2 & \multirow{2}{*}{ Orgamika F } & $1 \cdot 10^{4}$ & 80 & 5 & 6.3 \\
\hline 3 & & $1 \cdot 10^{8}$ & 80 & 4 & 5.0 \\
\hline 4 & $\begin{array}{l}\text { Vitavax 200, 75\% } \\
\text { (standard) }\end{array}$ & $10 \mathrm{~g} / \mathrm{kg}$ & 80 & 6 & 7.5 \\
\hline \multicolumn{6}{|c|}{ Kohlrabi } \\
\hline 1 & Control & - & 80 & 15 & 18.8 \\
\hline 2 & \multirow{2}{*}{ Orgamika F } & $1 \cdot 10^{4}$ & 80 & 4 & 5.0 \\
\hline 3 & & $1 \cdot 10^{8}$ & 80 & 3 & 3.8 \\
\hline \multirow[t]{2}{*}{4} & $\begin{array}{l}\text { Vitavax 200, 75\% } \\
\text { (standard) }\end{array}$ & $10 \mathrm{~g} / \mathrm{kg}$ & 80 & 5 & 6.3 \\
\hline & $\mathrm{LSD}_{05}$ & & & & 2.5 \\
\hline
\end{tabular}

In the first direction, the experiments were carried out in a greenhouse nursery, in which white cabbage seeds were sown for 24 hours in a titrated suspension of Orgamika $\mathrm{F}$ biopreparation $1 \cdot 10^{8} \mathrm{CFU} / \mathrm{ml}$. The seeds were treated with water-soaked seeds as a control option and Vitavax 200, 75\% seed fertilizer at $10 \mathrm{~g} / \mathrm{kg}$.

In the second direction, the experiments were continued with seedlings obtained from seeds treated in the above options. 
Table 2. Biological efficacy of Orgamika F biopreparation against fusarium disease of cabbage and cole vegetable crops.

\begin{tabular}{|c|c|c|c|c|}
\hline$\#$ & Experiment options & $\begin{array}{l}\text { Titer of preparation for } \\
\text { seed treatment (CFU/ml) } \\
\text { or discharge norms }\end{array}$ & $\begin{array}{c}\text { Infection with } \\
\text { fusarium disease, } \\
\%\end{array}$ & Bioproductivity, \% \\
\hline 1 & 2 & 3 & 4 & 5 \\
\hline \multicolumn{5}{|c|}{ White cabbage } \\
\hline 1 & Control & - & 33.2 & - \\
\hline 2 & \multirow{2}{*}{ Orgamika F } & $1 \cdot 10^{4}$ & 10.0 & 69.9 \\
\hline 3 & & $1 \cdot 10^{8}$ & 8.4 & 74.7 \\
\hline 4 & $\begin{array}{l}\text { Vitavax } 200,75 \% \\
\text { (standard) }\end{array}$ & $10 \mathrm{~g} / \mathrm{kg}$ & 13.1 & 60.5 \\
\hline \multicolumn{5}{|c|}{ Cauliflower } \\
\hline 1 & Control & - & 31.7 & - \\
\hline 2 & \multirow{2}{*}{ Orgamika F } & $1 \cdot 10^{4}$ & 8.8 & 72.2 \\
\hline 3 & & $1 \cdot 10^{8}$ & 7.9 & 75.1 \\
\hline 4 & $\begin{array}{l}\text { Vitavax } 200,75 \% \\
\text { (standard) }\end{array}$ & $10 \mathrm{~g} / \mathrm{kg}$ & 12.0 & 62.1 \\
\hline \multicolumn{5}{|c|}{ Chinese cabbage } \\
\hline 1 & Control & - & 27.3 & - \\
\hline 2 & \multirow{2}{*}{ Orgamika F } & $1 \cdot 10^{4}$ & 7.5 & 72.5 \\
\hline 3 & & $1 \cdot 10^{8}$ & 6.5 & 76.2 \\
\hline 4 & $\begin{array}{l}\text { Vitavax } 200,75 \% \\
\text { (standard) }\end{array}$ & $10 \mathrm{~g} / \mathrm{kg}$ & 10.2 & 62.6 \\
\hline \multicolumn{5}{|c|}{ Red cabbage } \\
\hline 1 & Control & - & 25.4 & - \\
\hline 2 & \multirow{2}{*}{ Orgamika F } & $1 \cdot 10^{4}$ & 7.5 & 70.4 \\
\hline 3 & & $1 \cdot 10^{8}$ & 5.9 & 76.8 \\
\hline 4 & $\begin{array}{l}\text { Vitavax } 200,75 \% \\
\text { (standard) }\end{array}$ & $10 \mathrm{~g} / \mathrm{kg}$ & 9.9 & 61.0 \\
\hline \multicolumn{5}{|c|}{ Savoy cabbage } \\
\hline 1 & Control & - & 22.5 & - \\
\hline 2 & \multirow{2}{*}{ Orgamika F } & $1 \cdot 10^{4}$ & 6.2 & 72.4 \\
\hline 3 & & $1 \cdot 10^{8}$ & 5.0 & 77.8 \\
\hline 4 & $\begin{array}{l}\text { Vitavax 200, 75\% } \\
\text { (standard) }\end{array}$ & $10 \mathrm{~g} / \mathrm{kg}$ & 8.3 & 63.1 \\
\hline \multicolumn{5}{|c|}{ Brocolli } \\
\hline 1 & Control & - & 17.5 & - \\
\hline 2 & \multirow{2}{*}{ Orgamika F } & $1 \cdot 10^{4}$ & 5.0 & 71.4 \\
\hline 3 & & $1 \cdot 10^{8}$ & 3.7 & 78.9 \\
\hline 4 & $\begin{array}{l}\text { Vitavax 200, 75\% } \\
\text { (standard) }\end{array}$ & $10 \mathrm{~g} / \mathrm{kg}$ & 6.7 & 61.7 \\
\hline \multicolumn{5}{|c|}{ Kohlrabi } \\
\hline 1 & Control & - & 10.0 & - \\
\hline 2 & \multirow{2}{*}{ Orgamika F } & $1 \cdot 10^{4}$ & 2.5 & 75.0 \\
\hline 3 & & $1 \cdot 10^{8}$ & 2.1 & 79.0 \\
\hline \multirow[t]{2}{*}{4} & $\begin{array}{l}\text { Vitavax } 200,75 \% \\
\text { (standard) }\end{array}$ & $10 \mathrm{~g} / \mathrm{kg}$ & 3.6 & 64.0 \\
\hline & $\mathrm{LSD}_{05}$ & & & 1.4 \\
\hline
\end{tabular}

Experiments on this farm with the Tashkent-10 variety of white cabbage were conducted in several directions.

In this case: 
Option 1 - control (the seed was treated with water);

Option 2 - the seed was treated only with a titrated suspension of Organic F $1 \cdot 10^{4}$ $\mathrm{CFU} / \mathrm{ml}$;

Option 3 - Seed and seedling root were treated with Orgamika F with a titrated suspension of $1 \cdot 10^{8} \mathrm{CFU} / \mathrm{ml}$;

Option $4-50 \mathrm{ml}$ suspension with Orgamika $\mathrm{F}$ was applied to the seed and root of the seedling before sowing with a titrated suspension of $1 \cdot 10^{8} \mathrm{CFU} / \mathrm{ml}$ and with a titrated suspension of $1 \cdot 10^{4} \mathrm{CFU} / \mathrm{ml}$ of this biopreparation 15 days after planting in the field;

Option 5 - template - Vitavax 200, 75\% seed treatment fungicide in the amount of 10 $\mathrm{g} / \mathrm{kg}$ of seed treated options were obtained.

As can be seen from Table 3, healthy and vigorous seedlings were obtained from the option treated with a titrated suspension of Orgamika F $1 \cdot 10^{8} \mathrm{CFU} / \mathrm{ml}$, and the number of seedlings infected with fusarium was $0.6-1.0 \%$ in the option. It was noted that $0.9-1.3 \%$ of seedlings obtained from seeds treated with a titrated suspension of this preparation $1 \cdot 10^{4}$ $\mathrm{CFU} / \mathrm{ml}$ were infected with fusarium disease.

In the water-treated control option, the disease prevalence was 3.7-5.8\%. It is known from references that representatives of fungi belonging to the family Trichoderma exhibit antagonistic properties against a number of pathogenic microorganisms in plants, and the antibiotics they secrete inhibit the growth of phytopathogenic microorganisms and accelerate plant growth and development [24].

Table 3. Effect of sowing of cabbage seeds treated with Orgamika F biopreparation on fusarium disease.

\begin{tabular}{|c|c|c|c|c|c|}
\hline \multirow{2}{*}{$\#$} & \multirow{2}{*}{$\begin{array}{l}\text { Experiment } \\
\text { options }\end{array}$} & \multirow{2}{*}{ 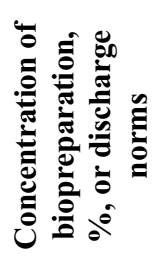 } & \multirow{2}{*}{ 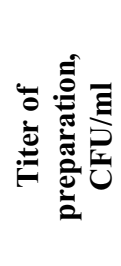 } & \multicolumn{2}{|c|}{$\begin{array}{c}\text { Incidence of fusarium } \\
\text { disease, } \%\end{array}$} \\
\hline & & & & 2017 & 2018 \\
\hline 1 & Control & - & - & 5.8 & 3.7 \\
\hline 2 & Orgamika F & - & $1 \cdot 10^{4}$ & 1.3 & 0.9 \\
\hline 3 & Orgamika F & - & $1 \cdot 10^{8}$ & 1.0 & 0.6 \\
\hline \multirow[t]{2}{*}{4} & $\begin{array}{c}\text { Vitavax 200, } \\
75 \% \\
\text { (stdandard) }\end{array}$ & $10 \mathrm{~g} / \mathrm{kg}$ & - & 1.5 & 1.2 \\
\hline & $\mathrm{LSD}_{05}$ & & & \multicolumn{2}{|c|}{2.3} \\
\hline
\end{tabular}

The above situation was observed due to the fact that the basis of the Orgamika $\mathrm{F}$ biopreparation used in the experiment was Trichoderma fungus. Experiments on the sowing of cabbage seeds in a suspension of Orgamic $F$ have shown that this preparation provides a basis for the production of energetic seedlings, free from pathogens that cause fusarium disease.

The yield retained in the seed-treated option of Orgamika F biopreparation was 2.3 tons/ha, which was 5.9\% higher than the control option (39.2 tons/ha) and amounted to 41.5 tons/ha. When Vitavax 200, a standard option, was treated with $75 \%$ white cabbage seeds at a rate of $10 \mathrm{~g} / \mathrm{kg}$, the total yield was 42.7 tons $/$ ha and $8.9 \%$ (3.5 tons $/$ ha) more than the control option (Table 4).

In view of this, before sowing of cabbage against fusarium disease with the suspension of Orgamika $\mathrm{F}$ biopreparation in seeds in the amount of $1 \cdot 10^{8} \mathrm{CFU} / \mathrm{ml}$ and before planting 
in the field of the obtained seedlings Orgamika F biopreparation at a concentration of $2 \%$ $\left(2 \cdot 10^{6} \mathrm{~kg}\right)$ found to be inoculated. However, 15 days after planting, it is recommended to apply Orgamika $\mathrm{F}$ biopreparation with a $0.25 \%$ suspension $\left(2.5 \cdot 10^{4} \mathrm{CFU} / \mathrm{ml}\right.$ titration) to produce $50 \mathrm{ml}$ of fluid culture under each seedling.

Table 4. Biological efficacy of Orgamika F biopreparation against fusarium disease

\begin{tabular}{|c|c|c|c|c|c|c|c|c|}
\hline \multicolumn{4}{|c|}{ Experiment options } & \multirow{3}{*}{ 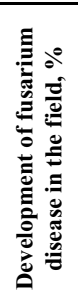 } & \multirow{3}{*}{ 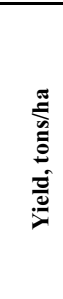 } & \multicolumn{2}{|c|}{$\begin{array}{l}\text { Preserved yield } \\
\text { (relative to } \\
\text { control) }\end{array}$} & \multirow{3}{*}{ 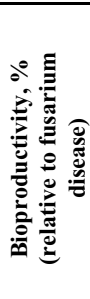 } \\
\hline & & \multicolumn{2}{|c|}{ Concentration of preparation } & & & & & \\
\hline \# & $\underset{\mathbf{n}}{\text { preparatio }}$ & $\begin{array}{c}\text { Seed } \\
\text { treatment }\end{array}$ & $\begin{array}{l}\text { Post-planting } \\
\text { treatment } * \%\end{array}$ & & & tons/ha & $\%$ & \\
\hline 1 & Control & $\begin{array}{c}\text { Seed } \\
\text { treatment } \\
\text { with water }\end{array}$ & $-*$ & 19.3 & 39.2 & - & - & - \\
\hline 2 & Orgamika F & \multirow{3}{*}{$\begin{array}{c}\text { Seeds treated } \\
\text { with a } \\
\text { suspension } \\
\text { with a titer of } \\
1 \cdot 10^{8} \\
\text { CFU } / \mathrm{ml}\end{array}$} & No treatment & 9.4 & 41.5 & 2.3 & 5.9 & 51.3 \\
\hline 3 & Orgamika F & & $\begin{array}{l}\text { Treated to the root of } \\
\text { the seedlings with a } \\
\text { concentration of } 2 \% \\
\left(2 \cdot 10^{6} \mathrm{CFU} / \mathrm{ml}\right) \\
\text { titrated suspension* }\end{array}$ & 6.0 & 45.4 & 6.2 & 15.8 & 68.9 \\
\hline 4 & Orgamika F & & $\begin{array}{l}\text { Treated with a } 2 \% \\
\text { suspension before } \\
\text { sowing and a } 0.25 \% \\
\text { titrated suspension } \\
\left(2 \cdot 10^{4} \mathrm{CFU} / \mathrm{ml}\right) 15 \\
\text { days after planting* }\end{array}$ & 4.0 & 47.4 & 8.2 & 20.1 & 79.3 \\
\hline 5 & $\begin{array}{c}\text { Vitavax } \\
200,75 \% \\
\text { (standard) }\end{array}$ & $10 \mathrm{~g} / \mathrm{kg}$ & - & 8.2 & 42.7 & 3.5 & 8.9 & 60.2 \\
\hline & $\mathrm{LSD}_{05}$ & & & 1.9 & 1.44 & & & \\
\hline
\end{tabular}

Note: * - Option 1: Control - with water to the seed; Option 2: with Orgamika F only to the seed; Option 3: with Orgamika $F$ to the seed and pre-planting seedling root with $2 \%$ suspension; and, Option 4: with Orgamika F to the root seed before sowing with a titrated $2 \%$ suspension $\left(2 \cdot 10^{6} \mathrm{CFU} / \mathrm{ml}\right)$ and 15 days after planting with a titrated $0.25 \%$ suspension $\left(2.5 \cdot 10^{4} \mathrm{CFU} / \mathrm{ml}\right)$ under each seedling at the rate of $50 \mathrm{ml}$ of fluid culture.

\section{Conclusions}

Orgamika $\mathrm{F}$ biopreparation not only reduced the damage of cabbage vegetable crops by fusarium disease, but also contributed to the improvement of quality indicators of seedlings. Of the experimental options, the best performance was shown by soaking the seeds in a $1 \cdot 10^{8} \mathrm{CFU} / \mathrm{ml}$ suspension of the biopreparation. The biological efficiency of the Orgamika $\mathrm{F}$ biopreparation in white cabbage at $1 \cdot 10^{4} \mathrm{CFU} / \mathrm{ml}$ titrated suspension $69.9 \%, 1 \cdot 10^{8}$ $\mathrm{CFU} / \mathrm{ml}$ titrated suspension. It was $74.7 \%$, which is $72.2 \%$ and $75.1 \%$ in cauliflower, $72.5 \%$ and $76.2 \%$ in Chinese cabbage, $70.4 \%$ and $76.8 \%$ in red cabbage, $72.4 \%$ and $77.8 \%$ in savoy cabbage, $71.4 \%$ and $78.9 \%$ in broccoli, and $75.0 \%$ and $79.0 \%$ in kohlrabi, respectively.

Biopreparation was carried out 3 times with Orgamika F biopreparation, with a suspension of $1 \cdot 10^{8} \mathrm{CFU} / \mathrm{ml}$ of titer to the seed before sowing, 15 days after planting in the seedling root and seedling field with $2 \%$ suspension of the biopreparation $\left(2 \cdot 10^{6} \mathrm{CFU} / \mathrm{ml}\right)$. When treated with a suspension with a concentration of $25 \%$ (titer of $2.5 \cdot 10^{4} \mathrm{CFU} / \mathrm{ml}$ ), the 
biological efficacy against fusarium disease of white cabbage was $79.3 \%$. With this in mind, the production was carried out with Orgamika $F$ biopreparation 3 times, with a suspension of $1 \cdot 10^{8} \mathrm{CFU} / \mathrm{ml}$ of seed titer before sowing, with $2 \%$ suspension of the biopreparation $\left(2 \cdot 10^{6} \mathrm{CFU} / \mathrm{ml}\right.$ titrated suspension) to the root and seedlings before planting. Therefore, it is recommended to treat the biopreparation with a suspension of $0.25 \%$ concentration $\left(2.5 \cdot 10^{4} \mathrm{CFU} / \mathrm{ml}\right.$ titration) 15 days after planting in the field.

Sowing seeds of cabbage vegetable crops against fusarium disease in a suspension of $1 \cdot 10^{8} \mathrm{CFU} / \mathrm{ml}$ of Orgamika $\mathrm{F}$ biopreparation before sowing not only reduces the disease, but also improves the quality of seedlings.

\section{References}

1. R.R. Azizbekyan, Biotechnology, 1, 69-77 (2013)

2. E.K. Burykhina, Protecting vegetable crops from pests and diseases, 3, 15-21 (1958)

3. O. Georgeva, G. Georgiev, Journal of Gavrshi, 1, 29-31 (2007)

4. V.M. Emets, R.A. Kulmatov, Doklady Biological Sciences, 271(1-6), 370-372 (1983)

5. B. Abdullaev, R.A. Kulmatov, A.A. Kist, Industrial Laboratory (USSR) (English translation of Zavodskaya Laboratoriya), 54(7), 710-713 (1989)

6. R.A. Kulmatov, V.S. Savenko, N. Dalonov, Geochemistry International, 29(5), 140148 (1992)

7. F.S. Djalilov, I.V. Korsak, Comparison of the effectiveness of two preparative forms of Rhizoplan, 79 (1995)

8. P. Zuev, Mycology and phytopathology, 5(6), 44 (1971)

9. V.S. Savenko, R.A. Kulmatov, Geochemistry International, 35(11), 1028-1030 (1997)

10. S. Islamov, N. Namozov, M. Saidova, D. Kodirova, E3S Web of Conferences, 244, $03028(2021)$

11. T.E. Ostonakulov, V.I. Zuev, Vegetables, 460 (2009)

12. N.M. Pidoblichko, Fungi - parasites of cultivated plants, 2, 300 (1977)

13. M. Urmanova, A. Kuziev, D. Burkhanova, D. Kadirova, N. Namozov, N. Shadieva, E3S Web of Conferences, 244, 02036 (2021)

14. N.Ch. Namozov, D.A. Kodirova, M.I. Usmonova, International journal of scientific \& technology research, 9(03), 5491-5493 (2020)

15. Y. Gafforov, R. Phookamsak, H.-B. Jiang, D.N. Wanasinghe, M. Juliev, Botany, 97(12), 671-680 (2019)

16. A.N. Allayarov, S.B. Abdurakhmanova, A.A. Khakimov, Epra International journal of research development (IJRD), 4(2), 118-122 (2019)

17. Y. Elad, S. Freeman, The Mycota XI Agricultural Applications. Ed. Kempken. Springer Verlag, Berlin Heidelberg, 93-109 (2002)

18. S.G. Kamilov, K.K. Nuraliev, R.K. Sattarova, A.A. Khakimov, Mikologiya i Fitopatologiya, 54(5), 313-319 (2020)

19. A.A. Khakimov, A.U. Omonlikov, S.B. Utaganov, GSC Biological and Pharmaceutical Sciences, 13(3), 119-126 (2020)

20. N. Korolev, M. Mamiev, Y. Elad, Communications in agricultural and applied biological sciences, 75(4), 705-707 (2010)

21. M.S. Mamiev, A.A. Khakimov, M.A. Zuparov, U.N. Rakhmonov, IOP Conference Proceedings : Earth and Environmental Sciences, 614, 012112 (2020) 
22. M. Mamiev, N. Korolev, Y. Elad, European Journal of Plant Pathology, 137(1), 79-91 (2013)

23. L.A. Siddiqui, S. Ehteshamul - Haque, A. Ghaffar, Pakistan J. Nematol., 17(1), 67-75 (1999)

24. M.A. Zuparov, A.A. Khakimov, M.S. Mamiev, A.N. Allayarov, International Journal on Emerging Technologies, 11(5), 50-55 (2020) 